\title{
THE EFFECT OF SERVANT LEADERSHIP ON PSYCHOLOGICAL OWNERSHIP: THE MODERATOR ROLE OF PERCEIVED ORGANIZATIONAL SUPPORT
}

\author{
*Bora YILDIZ \\ **Harun YILDIZ \\ *Turkish Naval Academy \\ **Turkish Air Force
}

\begin{abstract}
Employees' positive attitudes towards to their organizations are vital for organizations in terms of their positive effects on employee behaviors. In the literature, there are numerous studies that investigate the positive employee attitudes. Despite the majority of the studies, psychological ownership, as a one of the positive employee attitudes, related studies are interestingly limited in the literature. In this respect, the primary purpose of this study is to investigate the effect of servant leadership on psychological ownership. After a review of psychological ownership related studies, two propositions are developed to draw attention to this issue. Accordingly, the proposed model consists of three variables, servant leadership as the independent variable, psychological ownership as depended variable, and perceived organizational support plays a moderator role in the servant leadership-psychological ownership relationship. Managerial and further research implications are forwarded.
\end{abstract}

Keywords: Perceived Organizational Support, Psychological Ownership, Servant Leadership.

\section{INTRODUCTION}

Psychological ownership has been a new phenomenon in the management field. Despite its emergence in the literature, as a distinct construct from other related concepts dates back two decades ego, interestingly there are limited researches that investigate its antecedents and consequences (see Table 1). Psychological ownership refers an attitude that (a) based on feeling of possessiveness without any formal ownership of target object, (b) it is not observed as easy as formal ownership, and (c) it can be developable regardless of target object is tangible or intangible (Rudmin and Berry, 1987; Pierce, et al., 2003; Mayhew et al. 2007; O’Driscoll et al. 2006; Van Dyne and Pierce, 2004).

In literature, there are many studies that investigate the effects of psychological ownership on positive outcomes such as, job satisfaction (Zehir et al. 2012b), organizational commitment (Mayhew et al., 2007; Zehir et al., 2003), organizational citizenship behavior (Van Dyne and Pierce, 2004), constructive deviant workplace behaviors (Yıldız, 2015; Yıldı et al., 2015a; Yıldız et al., 2015b), organizational commitment (Sieger et al., 2011) etc. On the other hand, there are also studies that investigate the possible predictors of psychological ownership such as internal locus of control (McIntyre et al., 2009), perceived control (Asatryan and Oh, 2008), perceived organizational support (Ötken, 2015), organizational justice (Ötken, 2015; Yıldız et al., 2015a; Yıldız et al., 2015b), participative decision making (Liu et al., 2012; Y1ldı et al., 2015a; Y1ldiz et al., 2015b) etc. In addition to above-mentioned studies, there are also studies with related to the effects of leadership styles on psychological ownership such as transformational leadership (Avey et al., 2009; Ghafoor et al., 2011) and ethical leadership (Avey et al., 2012). Given the leaders' positive effects on employee behaviors and attitudes, servant leadership, as a one of the new leadership styles, related studies interestingly have been overlooked in the current literature. Leaders are important actors, who have a potential of influence organizational milieu, organizational climate (Grojean et al., 2004), organizational voice (Kılıç et al., 2014), and firm and employee performance (Zehir et al., 2011; Zehir and Erdoğan, 2011; Özşahin et al., 2011; Zehir et al., 2012a). Similarly, Yukl (2002) states that leaders have significant effects on their followers as a role model. Also, Elçi et al. (2012) state that ethical leadership and leadership effectiveness have negative impact on turnover intention and job stress. Supportively, Alpkan et al. (2005) found a positive relationship among leadership styles, organizational trust, organizational justice, 
organizational commitment, job satisfaction and organizational citizenship behavior. Therefore, it can be said that leaders are significant predictors of their followers' perceptions, attitudes, and behaviors. In light of these explanations, we propose that servant leadership, which refers to "increased service to others; a holistic approach to work; promoting a sense of community; and the sharing of power in decision making" (Smith, 2005, p. 4), may be one of the drivers of psychological ownership. Moreover, the proposed relationship between servant leadership and psychological ownership will be stronger when perceived organizational support is high. According to these propositions, the present study has two research questions: (a) is servant leadership an antecedent of psychological ownership? (b) does perceived organizational support have a moderator role in servant leadership-psychological ownership relationship?

In this paper, it is argued that employees' servant leadership perceptions play a significant role in the emergence of their psychological ownership attitudes, and high-level perceived organizational support has booster effect in this relationship as a moderator.

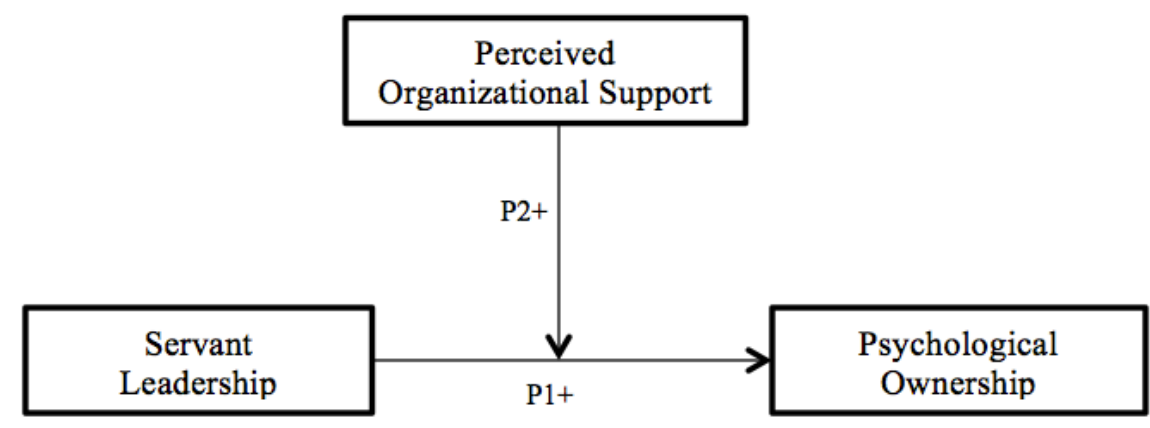

Figure 1. Theoretical Model

\section{THEORETICAL BACKGROUND}

Social exchange theory (Blau, 1964) suggests that behaviors shaped by perceptions and attitudes. According to this theory, behaviors are the product of an exchange relationship. On the other hand, Social learning theory (Bandura 1977, 1986) suggests that when there are role models in the workplace, individuals will try to emulate these models, and thereby those models will affect their attitudes and behaviors. Similarly, the theory of reasoned action (Ajzen and Fishbein, 1977, 1980) suggests that attitudes play a critical role on the relationship between perceptions and behaviors. As aforementioned, leaders are important role models for their followers (Yukl, 2002). There are numerous studies in the literature that stress the influence of role models on positive (Mayer et al., 2009, 2010; Picollo et al., 2010; Demirtas and Akdoğan, 2014; Demirtas, 2015) and negative (Kılıç et al., 2014; Uddien et al., 2014; Van Gils et al., 2015) employee behaviors. In the following section the concept definition of psychological ownership, the effect of servant leadership on psychological ownership and the proposed mediator role of perceived organizational support in this relationship are presented.

\section{Psychological Ownership}

Psychological ownership defined as "that state where an individual feels as though the target of ownership or a piece of that target is 'theirs' (i.e., it is MINE!)” (Pierce, et al., 2003). Similarly, Mayhew et al. (2007) defined this construct as "a feeling of possession in the absence of any formal or legal claims of ownership". Pierce et al. (2001, 2003) also defined this construct as "an attitude with affective and cognitive elements". In other words, this phenomenon emphasizes that attitudes are important and tacit variables that link perceptions to behaviors. Pierce et al. (2001) state that this construct consists of three sub-dimensions namely belongingness, self-efficacy, and self-identity. In addition to these sub-dimensions Avey et al. (2009) in their study, which try to define the components of psychological ownership, added one more sub-dimensions to this construct namely accountability. From these explanations, we can say that the construct of psychological ownership consists of four sub-dimensions. On the other hand, Mayhew et al. (2007) categorized this construct into two sub-categories namely organization-based psychological ownership and job-based psychological ownership. Organization-based psychological ownership refers to the feeling of possession 
Journal of Global Strategic Management | V. 9 | N. 2 | 2015-December | isma.info | 65-77 | DOI: 10.20460/JGSM.2015915574 developed by members of the organization as a whole towards to the organization. On the other hand, jobbased psychological ownership refers to the feeling of possession towards to a specific job that is developed by individuals. In this respect, in this study, to uncover organizational level determinants of psychological ownership, we focused on the organization-based psychological ownership. The studies that investigate the antecedents and consequences of psychological ownership are presented in Table1.

Table 1. Psychological Ownership Related Studies

\begin{tabular}{|c|c|c|c|}
\hline Reference & Antecedents & Dependent Variable & - Consequences \\
\hline $\begin{array}{l}\text { Mayhew et al. } \\
\text { (2007) }\end{array}$ & - Autonomy & $\begin{array}{l}\text { - Job-based psychological } \\
\text { ownership } \\
\text { - Organization-based } \\
\text { psychological ownership }\end{array}$ & $\begin{array}{l}\text { - Job satisfaction } \\
\text { - Organizational commitment }\end{array}$ \\
\hline $\begin{array}{l}\text { Van Dyne and } \\
\text { Pierce (2004) }\end{array}$ & & Psychological ownership & $\begin{array}{l}\text { - Organizational commitment } \\
\text { - Job satisfaction } \\
\text { - Self esteem } \\
\text { - Organizational citizenship } \\
\text { behavior }\end{array}$ \\
\hline $\begin{array}{l}\text { McIntyre et al. } \\
\text { (2009) }\end{array}$ & $\begin{array}{l}\text { - Individualism } \\
\text { - Internal focus of control } \\
\text { - Employee motives }\end{array}$ & Psychological ownership & \\
\hline $\begin{array}{l}\text { Asatryan and } \mathrm{Oh} \\
(2008)\end{array}$ & $\begin{array}{l}\text { - Sense of belongingness } \\
\text { - Identification } \\
\text { - Perceived control }\end{array}$ & Psychological ownership & $\begin{array}{l}\text { - Relationship intentions } \\
\text { - Word of mouth } \\
\text { communication } \\
\text { - Competitive resistance } \\
\text { - Payment willingness }\end{array}$ \\
\hline Özler et al. (2008) & $\begin{array}{l}\text { - Job satisfaction } \\
\text { - Tenure } \\
\text { - Participative organizational } \\
\text { climate }\end{array}$ & Psychological ownership & $\begin{array}{l}\text { - Organizational commitment } \\
\text { - Organizational citizenship } \\
\text { behavior }\end{array}$ \\
\hline Ötken, (2015) & $\begin{array}{ll}\text { - } & \text { Perceived organizational support } \\
\text { (moderator) }\end{array}$ & Psychological ownership & \\
\hline $\begin{array}{l}\text { Yıldiz et al. (2015a) } \\
\text { Yıldız (2015) } \\
\text { Yıldız et al. (2015b) }\end{array}$ & $\begin{array}{l}\text { - Perceived organizational justice } \\
\text { - Participative decision making } \\
\text { - Person-organization fit }\end{array}$ & Psychological ownership & $\begin{array}{l}\text { - Innovative constructive } \\
\text { deviant workplace behavior }\end{array}$ \\
\hline Sieger et al. (2011) & $\begin{array}{l}\text { - Distributive justice } \\
\text { - } \text { Procedural justice }\end{array}$ & Psychological ownership & $\begin{array}{l}\text { - Affective commitment } \\
\text { - Job satisfaction }\end{array}$ \\
\hline Avey et al. (2012) & - Ethical leadership & Psychological ownership & - Job satisfaction \\
\hline Liu et al. (2012) & $\begin{array}{l}\text { - Self-management team climate } \\
\text { - Participative decision making }\end{array}$ & Psychological ownership & $\begin{array}{l}\text { - Affective commitment } \\
\text { - Organizational citizenship } \\
\text { behavior } \\
\text { - Organization-based self } \\
\text { esteem }\end{array}$ \\
\hline $\begin{array}{l}\text { Ghafoor et al. } \\
\text { (2011) }\end{array}$ & $\begin{array}{l}\text { - Transformational leadership } \\
\text { - Employee commitment }\end{array}$ & Psychological ownership & • Employee performance \\
\hline $\begin{array}{l}\text { Vandewalle et al. } \\
\text { (1995) }\end{array}$ & $\begin{array}{l}\text { - Psychological ownership } \\
\text { - Organizational commitment } \\
\text { (mediator) }\end{array}$ & Extra-role behaviors & \\
\hline
\end{tabular}


Journal of Global Strategic Management | V. 9 | N. 2 | 2015-December | isma.info | 65-77 | DOI: 10.20460/JGSM.2015915574

Table 1. continued

\begin{tabular}{|c|c|c|c|}
\hline Reference & Antecedents & Dependent Variable & - Consequences \\
\hline Ispirli (2014) & - Psychological ownership & $\begin{array}{l}\text { - Employee knowledge } \\
\text { hiding behaviors }\end{array}$ & \\
\hline Jussila et al. (2015) & $\begin{array}{l}\text { - Psychological ownership } \\
\text { (mediator) } \\
\text { - Power of Control } \\
\text { - Engagement }\end{array}$ & $\begin{array}{l}\text { - Motivational outcomes } \\
\text { - Attitudinal outcomes } \\
\text { - Behavioral outcomes }\end{array}$ & \\
\hline $\begin{array}{l}\text { Chi and Han } \\
\text { (2008) }\end{array}$ & $\begin{array}{ll}\text { - } & \text { Distributive justice } \\
\text { - } & \text { Procedural justice } \\
\text { - } & \text { Profit sharing plans } \\
\text { - } & \text { Participative decision making } \\
\text { - } & \text { Access to job information } \\
\text { - } & \text { Organizational justice } \\
& \text { (mediator) } \\
\end{array}$ & - Psychological ownership & \\
\hline Qiu et al (2015) & $\begin{array}{ll}\text { - } & \text { Performance appraisal } \\
& \text { purpose } \\
\text { - } & \text { Self-efficacy (mediator) } \\
\text { - } & \text { Psychological ownership } \\
& \text { (mediator) }\end{array}$ & $\begin{array}{l}\text { - Individual proactive } \\
\text { behaviors } \\
\text { - Interpersonal proactive } \\
\text { behaviors } \\
\text { - Organizational proactive } \\
\text { behaviors } \\
\end{array}$ & \\
\hline Lee and Suh (2015) & $\begin{array}{l}\text { - Autonomy } \\
\text { - Membership duration } \\
\text { - Self-discrepancy }\end{array}$ & - Psychological ownership & $\begin{array}{l}\text { - Satisfaction } \\
\text { - Self-concept } \\
\text { - Knowledge contribution }\end{array}$ \\
\hline Knapp et al. (2014) & $\begin{array}{l}\text { - Perceived insider status } \\
\text { - Psychological ownership }\end{array}$ & $\begin{array}{l}\text { - Job satisfaction } \\
\text { - Turnover } \\
\end{array}$ & \\
\hline $\begin{array}{l}\text { Atalay and Özler, } \\
\text { (2013) }\end{array}$ & - Organizational justice & - Psychological ownership & \\
\hline $\begin{array}{l}\text { Henssen et al. } \\
\text { (2014) }\end{array}$ & $\begin{array}{l}\text { - CEO autonomy } \\
\text { - Psychological ownership } \\
\text { (mediator) }\end{array}$ & $\begin{array}{l}\text { - Servant leadership } \\
\text { behavior }\end{array}$ & \\
\hline $\begin{array}{l}\text { Olckers, and van } \\
\text { Zyle (2015) }\end{array}$ & $\begin{array}{l}\text { - Employment equity } \\
\text { - Irk (moderator) }\end{array}$ & - Psychological ownership & \\
\hline $\begin{array}{l}\text { O’Driscoll et al. } \\
\text { (2006) }\end{array}$ & - Work environment structure & - Psychological ownership & $\begin{array}{l}\text { - Organizational citizenship } \\
\text { behavior } \\
\text { - Organizational commitment }\end{array}$ \\
\hline $\begin{array}{l}\text { Wagner et al. } \\
\text { (2003) }\end{array}$ & $\begin{array}{l}\text { - Participation in groups } \\
\text { - Autonomy climate }\end{array}$ & - Psychological ownership & $\begin{array}{l}\text { - Employee attitudes towards to } \\
\text { organization } \\
\text { - Financial performance }\end{array}$ \\
\hline $\begin{array}{l}\text { Chung and Moon } \\
\text { (2011) }\end{array}$ & $\begin{array}{l}\text { - } \text { Collectivist propensity } \\
\text { - } \text { Psychological ownership } \\
\text { (moderator) }\end{array}$ & $\begin{array}{l}\text { - Organizational and } \\
\text { Interpersonal } \\
\text { Constructive Deviant } \\
\text { Workplace behavior }\end{array}$ & \\
\hline $\begin{array}{l}\text { Demirkaya and } \\
\text { Simşek Kandemir } \\
\text { (2014) }\end{array}$ & $\begin{array}{l}\text { - Education level } \\
\text { - Experience } \\
\text { - Gender } \\
\text { - Age }\end{array}$ & - Psychological ownership & \\
\hline
\end{tabular}

As seen from Table 1, there are numerous studies about the psychological ownership. Clearly, these studies show that there are some individual and organizational level predictors of it. For instance, past researches show that psychological ownership is positively related to organizational commitment, job satisfaction, organization-based self-esteem, performance, and organizational citizenship behaviors (Van Dyne and Pierce, 2004). Similarly, Mayhew et al. (2007) state that psychological ownership is positively related to job satisfaction, organizational commitment, autonomy, employee silence, in-role behaviors and helping 
Journal of Global Strategic Management | V. 9 | N. 2 | 2015-December | isma.info | 65-77 | DOI: 10.20460/JGSM.2015915574

behaviors. Yildız et al. (2015) and Yildız (2015) state that psychological ownership is one of the predictors of innovative constructive deviant workplace behaviors. Additionally, their findings also show that psychological ownership as an attitude has a mediator role in the relationship between some employee perceptions (i.e. person-organization fit, perceived organizational justice, participative decision making) and innovative constructive deviant workplace behaviors. Supportively, Özler et al. (2008) found a positive and significant relationship among psychological ownership, organizational commitment, participative organizational climate, job satisfaction, and organizational citizenship behaviors. Ötken (2015) also investigated the effect of perceived organizational support on psychological ownership, and the mediator role of organizational justice. Her findings show that there are positive relations among those variables. Interestingly, the findings of that study show that organizational justice has a moderating effect on the perceived organizational support-psychological ownership relationship when the level of perceived organizational justice is low. In comparison with the majority of studies in the literature, this finding contradicts with the past researches in terms of the low-level organizational justice' moderator effect (Aryee et al., 2002; Tyler and Blader, 2003; Robbins et al., 2000; Roch and Shanock, 2006). In addition to abovementioned studies, there are also studies that investigate the effects of leadership styles on psychological ownership i.e. ethical leadership and transformational leadership (Ghafoor et al., 2011; Avey et al., 2009, 2012). In Ghafoor et al.' (2011) study, they found a positive and significant relationships among psychological ownership, employee performance, and transformational leadership. Moreover, their findings show that psychological ownership has a partial mediating effect on transformational leadership-employee performance relationship. Correspondingly, Avey et al. (2009) investigated the possible predictors of psychological ownership and found that there is a positive relationship between transformational leadership and psychological ownership. Additionally, Avey et al. (2012) investigated the effect of ethical leadership on employee voice, psychological ownership, psychological ownership and job satisfaction. Their findings show that ethical leadership is one of the significant and positive drivers of psychological ownership and the other variables. As understood from those studies, it is easy to say that followers' perception of leadership styles is one of the predictors of psychological ownership. However, taking into account all of these arguments, there are also some different types of leadership styles except for transformational and ethical leadership i.e. servant leadership. Despite the positive effects of servant leadership on positive outcomes well established in the literature (Greenleaf, 2015; Ürü Sanı et al. 2013; Demirel et al., 2013; Rivkin et al., 2014; Dal and Çorbacıoğlu, 2014; Barbuto and Wheeler, 2002; Vondey, 2010), interestingly servant leadershippsychological ownership relationship has been under-researched in the literature until now.

\section{Servant Leadership}

The world is proclaiming for ethical and effective leadership that serves others, strives to reach their potential and creates a shared vision (Page and Wong, 2000). In this aspect, as a result of satisfying needs of others as a priority, emphasizing power-sharing and serving dimension of the leadership emerged a leadership style called "servant leadership" (Greenleaf, 1977, 2002, 1996, 2015). Indeed, Robert K. Greenleaf firstly proposed servant-leadership in 1970. Page and Wong (2000) defined servant leadership style as "a leader whose primary purpose for leading is to serve others by investing in their development and well-being for the benefit of accomplishing tasks and goals for the common good.” According to Greenleaf (1996), servant leadership is defined as "increased service to others; a holistic approach to work; promoting a sense of community; and the sharing of power in decision making." Servant leaders develop strong supportive relationships with all employees and members of the group (Greenleaf, 1996). Also, they affect employees to exhibit positive emotions and behaviors (Dannhauser, 2007). Therefore, servant leadership promotes emotional health, organizational wisdom, and self-determination. Similarly, when leaders exhibit servant leadership style, organizations may gain positive outcomes such as employees' extra effort, employees' satisfaction, and perceptions of organizational effectiveness (Barbuto and Wheeler, 2002).

In the literature, a number of studies are being done on servant leadership. In these studies, in general, the relationship of servant leadership style with employees' attitudes and behaviors has been investigated. In the meantime, some studies have been focused on antecedents of servant leadership such as conscientiousness (Krekeler, 2010; Hunter et al. 2013), agreeableness (Krekeler, 2010) and extraversion (negatively) traits (Hunter et al. 2013). Servant leadership affects a wide range of positive organizational outcomes, such as organizational citizenship behavior (Ürü San1 et al. 2013; Vondey, 2010; Barbuto and Wheeler, 2002), helping and sales behavior, service climate (Hunter et al. 2013), leader-member exchange (Dal and 


\section{Journal of Global Strategic Management | V. 9 | N. 2 | 2015-December | isma.info | 65-77 | DOI: 10.20460/JGSM.2015915574}

Çorbacıoğlu, 2014; Barbuto and Wheeler, 2002), the quality of service (Demirel et al. 2013), employees’ psychological health (Rivkin et al. 2014), employee satisfaction (Barbuto and Wheeler, 2002; Washington, 2007), person-organization fit and organizational identification (Vondey, 2010) and organizational effectiveness (Barbuto and Wheeler, 2002), organizational commitment (Washington, 2007; Rimes, 2011), individual performance (Ürü Sanı et al. 2013), conflict management styles (collaborative, accommodating, and compromising) (Orlan and DiNatale-Svetnicka, 2013) and other measures of performance (Barbuto and Wheeler, 2002). On the other hand, some studies found a negative relationship between servant leadership and certain negative variables, such as competitive and avoidance conflict management strategies (Orlan and DiNatale-Svetnicka, 2013), emotional exhaustion and depersonalization (job strain), ego depletion and need for recovery (day-level indicators of strain) (Rivkin et al., 2014), and turnover intentions and disengagement (Hunter et al. 2013).

In addition to above-mentioned studies, we suggest social learning theory (Bandura 1977, 1986) as a theoretical basis to understand servant leadership and to explain the relationship of servant leadership with employees' attitudes and behaviors. Social learning theory, enlighten the reasons of some individual characteristics of the leader and situational influences which are related to followers' perceptions of a leader as a servant leader. According to the theory, individuals learn by giving attention to role models, and imitate attitudes, values and behaviors of appealing and reliable models (Bandura 1986; Brown and Treviño, 2006, p. 597). Since they meet needs of others as a priority and serve them, leaders are important source of such role modelling in the eyes of others (Demirtas, 2015). Therefore, if we consider social learning theory, servant leadership style will produce positive attitudes i.e. psychological ownership. It follows that;

Proposition 1: Employees servant leadership perception is a predictor of psychological ownership.

\section{Moderator: Perceived Organizational Support}

Perceived organizational support theory is closely related with the Blau's (1964) social exchange theory (Aselage and Eisenberger, 2003). In other words, these two theories stress an exchange relationship between employee and employer relationship. Perceived organizational support (POS) is defined as "employees general belief that their work organization values their contribution and cares about their wellbeing" (Rhoades and Eisenberger, 2002). As understood from this definition, POS is associated with the employees' themselves and their contributions in organization eyes. According to POS theory, the emergence of POS is related to employees' propensity to encourage organization's humanlike characteristics (Eisenberger et al., 1986). Rhoades and Eisenberger (2002), in their meta-analysis, categorized POS'antecedents into three general sub- dimensions namely fairness, supervisor support, and organizational rewards and job conditions. Fairness stresses the role of procedural justice on the employees POS (Shore and Shore, 1995; Rhoades and Eisenberger, 2002). According to that view employee's procedural justice is one of the drivers of POS. In other words, if employees perceive distribution of resources as fair, employees' POS will be affected positively. On the other hand, supervisor support has also a significant effect on POS. As previously mentioned, since role models have an influence on followers (Mayer et al., 2009, 2010; Picollo et al., 2010; Demirtas and Akdoğan, 2014; Demirtas, 2015), and since supervisors have an authority on subordinates such as evaluating their performances and assigning tasks (Eisenberger et al., 1986; Levinson, 1965) they have a significant role on employees' POS. Similarly, organizational rewards and job conditions refer to promotions, role stressors, job security, autonomy, training recognition and pay etc. (Rhoades and Eisenberger, 2002). In light of these explanations, it is easy to say that there are numerous managerial, organizational and individual factors that related with to POS.

After a comprehensive literature review, Rhoades and Eisenberger' (2002) in their meta-analytic study, state that POS is related to the some individual and organizational outcomes. At the individual level, POS is positively related to job satisfaction and positive mood. On the other hand, at the organizational level it is positively related to the performance, affective commitment and lessened withdrawal behaviors. In addition to that study, Eisenberger et al. (1986) found a positive relationship between POS and employee affective commitment, and negative relationship between POS and absenteeism. Supportively, Wu and Liu (2014) found a positive relationship among POS, and organizational citizenship behavior and organizational commitment. Alpkan et al. (2010) investigate the effect of organizational support on innovative performance and moderating effects of human capital on this relationship. Their findings show that organizational support is positively related to the human capital and innovative performance. Shanock and Eisenberger (2006) found 
Journal of Global Strategic Management | V. 9 | N. 2 | 2015-December | isma.info | 65-77 | DOI: 10.20460/JGSM.2015915574 a positive relationship between POS (supervisor POS, subordinate POS) and performance (in-role performance and extra-role performance). Yildız et al. (2015c), in their moderated mediation model, investigated the moderating effect of POS on the relationship between risk taking propensity and network building. Their findings show that employees who have risk-taking propensity are more prone to develop network building to exhibit innovative constructive deviant workplace behaviors when perceived organizational support level is low. Past studies also indicate that POS is positively related to extra-role behaviors (Chen et al., 2009), procedural justice and organizational citizenship behavior (Moorman et al., 1998; Wayne et al., 1997; Shore and Wayne, 1993), leader-member exchange (Erdoğan et al., 2004), affective commitment (Wayne et al., 1997; Shore and Wayne, 1993), organizational commitment, job satisfaction, supportive human resources practices i.e. participation in decision making, fairness of rewards, and growth opportunities (Allen et al., 2003). Of course, POS also negatively related to the some outcomes, such as withdrawal behaviors (Allen et al., 2003). In addition to these studies, Erdogan and Enders (2007) investigated the moderating effect POS on the relationship between LMX-job performance relationship, and LMX-job satisfaction relationship. Their findings show that the high-level POS has a moderator role in both LMX-job performance relationship and LMX-job satisfaction relationship. Shore and Wayne (1993) emphasizes that POS leads to the feeling of obligation that contributes to the emergence of extra-role behaviors.

In light of the above-mentioned studies, POS is one of the booster predictors of positive outcomes. Blau's (1964) social exchange explanation and Bandura's $(1977,1986)$ social learning perspective suggest those employees' attitudes and behaviors are the results of their perceptions, exchange relations with the others, and trying to emulate role models. According to this theories, since employees' servant leadership perceptions is a positive source of positive outcomes, and since psychological ownership is supposed as an outcome of followers' servant leadership perceptions, we propose that servant leadership-psychological ownership relationship will be stronger when perceived organizational support is high. It follows that;

Proposition 2: Perceived organizational support moderates the positive relationship between followers' servant leadership perception and psychological ownership.

\section{CONCLUSION}

In this study, we focused on the psychological ownership as a positive attitude. Although there are plenty of studies in the literature, we realize that effective reasons behind of it contrary to expectations are limited. In this respect, after a literature review on psychological ownership, it was determined that some rarely studied drivers of it under-researched, i.e. servant leadership and perceived organizational support. According to these explanations, two propositions was developed to draw attention to servant leadership and perceived organizational support. To simplify these relations, we visualized the proposed model in Figure 1.

Within the context of Blau's (1964) social exchange theory and Bandura's $(1977,1986)$ social learning theory, there are an exchange relationship between employers-employee relationships and learning by giving attention to and imitating the behaviors of appealing models. Moreover, the maintenance of this relationship depends on the continuation of this exchange relationship. In this context, perceptions, attitudes, and behaviors are the main actors of these theories. In other words, attitudes are the products of perceptions and emulating of leaders as well as behaviors are the product of attitudes and perceptions. According to these theories, employees who perceive their organizational milieu and their leader as positive, they will fell obligation to reply this positive perception with positive attitudes or behaviors. In light of these theoretical explanations, we propose that if employees' servant leadership perception is high, they will feel gratitude towards to their leaders, in turn, their organization because of the good relationship with their leaders and desired organizational climate. As previously mentioned, these factors are the basis of the feeling of possession that constitutes the core of psychological ownership. On the other hand, past researches indicate that perceived organizational support is one of the key determinants of positive employee behaviors and attitudes. Since this perception cultivates or strengthens the feeling of commitment, and since there is a strong relationship between commitment and psychological ownership, we propose that there is a positive relationship between servant leadership and psychological ownership, and this relationship is stronger when employees' perceived organizational support is high.

The proposed model of this study (see Figure 1) could be beneficial for organizations, practitioners and academicians. By means of this study, top managers and HRM professionals might be aware of the 
importance of the attitude of psychological ownership. Correspondingly, they might provide an organizational milieu where servant leaderships are dominant in the organizations. Similarly, employee focused organizational politics might be designed. For instance, organizations should look their employees as a value and care about their well-beings. Additionally, providing the sense of belongingness and supportive climate for employees should be in the list of priorities of organizations. To flourish positive and extra-role behaviors of employees, HRM managers should look psychological ownership as a must. Also, to achieve above-mentioned desired conditions, organizations should provide a fair atmosphere in the workplace, constitute a trust-based climate, provide comfortable working conditions, use effective personal selection and appraisal activities, provide ethical and moral standards, and value employees above other concerns.

Despite the strengths of this study, it is not without its limitations. Firstly, this study focused on psychological ownership as a positive employee attitude. However, given the complex nature of human, there might be numerous employee attitudes that go beyond the scope of this study. Secondly, we investigated the servant leadership as a one of the perception-based predictors of psychological ownership. Further researches should look their effects on psychological ownership separately or collectively because there are also different leadership styles. Thirdly, in this study we discussed the moderating effect of perceived organizational support. In view of the limited studies in the literature that related to the psychological ownership, there are many potential variables to investigate their conditional effects on this relationship such as organizational justice, organizational trust. In addition to these limitations, to reach a holistic view, further researches should investigate the antecedents and consequences of psychological ownership at the same time. Last but not least, despite the robust theoretical rationales, this study should be tested empirically by further researches to achieve its primary purpose. 
Journal of Global Strategic Management | V. 9 | N. 2 | 2015-December | isma.info | 65-77 | DOI: 10.20460/JGSM.2015915574

\section{REFERENCES}

Ajzen, I., \& Fishbein, M. (1977). Attitude-Behavior Relations: A Theoretical Analysis and Review of Empirical Research. Psychological Bulletin, 84(5), 888.

Ajzen, I., \& Fishbein, M. (1980). Understanding Attitudes and Predicting Social Behaviour. Prentice Hall; Englewood Cliffs, NJ

Allen, D. G., Shore, L. M., \& Griffeth, R. W. (2003). The Role of Perceived Organizational Support and Supportive Human Resource Practices in The Turnover Process. Journal of Management, 29(1), 99-118.

Alpkan, L., Bulut, C., Gunday, G., Ulusoy, G., \& Kilic, K. (2010). Organizational Support for Intrapreneurship and Its Interaction with Human Capital to Enhance Innovative Performance. Management Decision, 48(5), 732-755.

Alpkan, L., Dilek, H., \& Bozloğan, R. (2005). Liderlik Tarzlarının Güven ve Adalet Algısı Yoluyla Örgütsel Bağlılık, Iş Tatmini ve Örgütsel Vatandaşlık Davranışı Üzerine Etkileri. Savunma Bilimleri Dergisi, 4(1), 4469.

Aryee, S., Budhwar, P. S. and Chen, Z. X. (2002). “Trust as a Mediator of The Relationship between Organizational Justice and Work Outcomes: Test of a Social Exchange Model”, Journal of Organizational Behavior, 23, 267-285.

Asatryan, V.S. and H. Oh, (2008), Psychological Ownership Theory: An Exploratory Application in the Restaurant Industry, Journal of Hospitality and Tourism Research, 32, 363-86.

Aselage, J., \& Eisenberger, R. (2003). Perceived Organizational Support and Psychological Contracts: A Theoretical Integration. Journal of Organizational Behavior, 24(5), 491-509.

Atalay, C. G. and Özler, D. E. (2013). A Research to Determine the Relationship between Organizational Justice and Psychological Ownership among Non-family Employees in a Family Business, Procedia-Social and Behavioral Sciences, 99, 247-256.

Avey, J. B., Avolio, B. J., Crossley, C. D. and Luthans, F. (2009). Psychological Ownership: Theoretical Extensions, Measurement and Relation to Work Outcomes, Journal of Organizational Behavior, 30(2), 173191.

Avey, J. B., Wernsing, T. S. and Palanski, M. E. (2012). Exploring the Process of Ethical Leadership: The Mediating Role of Employee Voice and Psychological Ownership, Journal of Business Ethics, 107(1), 21-34.

Blau, P. M. (1964). Exchange and Power in Social Life. Transaction Publishers

Barbuto, J. E., \& Wheeler, D. W. (2006). Scale Development and Construct Clarification of Servant Leadership. Group \& Organization Management, 31(3), 300-326.

Erdogan, B., \& Enders, J. (2007). Support from the Top: Supervisors' Perceived Organizational Support As a Moderator of Leader-Member Exchange to Satisfaction and Performance Relationships. Journal of Applied Psychology, 92(2), 321.

Chung, Y. W. and Moon, H. K. (2011). The Moderating Effects of Collectivistic Orientation on Psychological Ownership and Constructive Deviant Behavior, International Journal of Business and Management, 6(12), 65-77.

Chi, N-W and Han, T-S. (2008). Exploring the Linkages between Formal Ownership and Psychological Ownership for the Organization: The Mediating Role of Organizational Justice, Journal of Occupational and Organizational Psychology, 81(4), 691-711.

Dal, L., \& Çorbacıoğlu, S. (2014). Hizmetkar Liderlik Davranışları ve Lider-Üye Etkileşimci Ilişkisi: Bir Devlet Üniversitesi Üzerine Araştırma. Süleyman Demirel Üniversitesi İktisadi ve İdari Bilimler Fakültesi Dergisi, 19(4), 287-310.

Demirel, E. T., Yatkın, A., Düşükcan, M., Derin, N., Çakınberk, A., \& Güven, M. (2013). Vatandaşların Belediye Hizmet Kalitesi Algılamaları Üzerinde Belediye Başkanlarının Liderlik (hükümdar/hizmetkâr) Özelliklerinin Belirleyiciliği: TRB-I Bölgesi Örneği. Çağdaş Yönetimler Dergisi, 22(2), 45-81 
Demirkaya, H. ve Şimşek Kandemir, A. (2014). 21. Yüzyılın Anahtar Rekabet Faktörü Olan Psikolojik Sahiplenme Üzerine Bir İşletme İncelemesi, Çalışma Dünyası Dergisi, 2(3). 7-21.

Demirtas, O. (2015). Ethical Leadership Influence at Organizations: Evidence From the Field. Journal of Business Ethics, 126(2), 273-284.

Demirtas, O., \& Akdogan, A. A. (2014). The Effect of Ethical Leadership Behavior on Ethical Climate, Turnover Intention, and Affective Commitment. Journal of Business Ethics, 1-9.

Einsenberger, R., Cummings, J., Aemeli, S., \& Lynch, P. (1997). Perceived Organizational Support, Discretionary Treatment, and Job Satisfaction. Journal of Applied Psychology, 82(5), 812-820.

Eisenberger, R., Huntington, R., Hutchison, S. \& Sowa, D. (1986). Perceived Organizational Support. Journal of Applied Psychology, 71, 500-507.

Elçi, M., Sener, İ, Aksoy, S., Alpkan, L., et al. (2012). The Impact of Ethical Leadership and Leadership Effectiveness on Employees’ Turnover Intention: The Mediating Role of Work Related Stress, 8th International Strategic Management Conference, Procedia - Social and Behavioral Sciences 58, 289 - 297

Erdogan, B., Kraimer, M. L., \& Liden, R. C. (2004). Work Value Congruence and Intrinsic Career Success: The Compensatory Roles of Leader-Member Exchange and Perceived Organizational Support. Personnel Psychology, 57(2), 305-332.

Ghafoor, A., Qureshi, T. M., Khan, M. A. and Hijazi, S. T. (2011). Transformational Leadership, Employee Engagement and Performance: Mediating Effect of Psychological Ownership, African Journal of Business Management, 5(17), 7391-7403.

Greenleaf, R. K. (2015). What Is Servant leadership? Retrieved November 24, 2015 from, https://greenleaf.org/what-is-servant-leadership/

Grojean, M. W., Resick, C. J., Dickson, M. W., \& Smith, D. B. (2004). Leaders, Values, and Organizational Climate: Examining Leadership Strategies for Establishing An Organizational Climate Regarding Ethics. Journal of Business Ethics, 55(3), 223-241.

Henssen, B., Voordeckers, W., Lambrechts, F. and Koiranen, M. (2014). The CEO Autonomy-Stewardship Behavior Relationship in Family Firms: The Mediating Role of Psychological Ownership, Journal of Family Business Strategy, 5(3), 312-322.

İspirli, D. (2014). Knowledge as An Object of Psychological Ownership and Knowledge Hiding via Territoriality among Knowledge Workers, Celal Bayar University, Published MSc Thesis.

Jussila, I., Tarkiainen, A., Sarstedt, M. and Hair, J. F. (2015). Individual Psychological Ownership: Concepts, Evidence, and Implications for Research in Marketing, Journal of Marketing Theory and Practice, 23(2), 121139.

K1lıç, R., Keklik, B. and Yıldız, H. (2014). Dönüştürücü, Etkileşimci ve Tam Serbesti Tanıyan Liderlik Tarzlarının Örgütsel Sessizlik Üzerindeki Etkisini Belirlemeye Yönelik Bir Araştırma, Yönetim ve Ekonomi: Celal Bayar Üniversitesi İktisadi ve İdari Bilimler Dergisi, 21(2), 249-268.

Knapp, J. R., Smith, B. R. and Sprinkle, T. A. (2014). Clarifying the Relational Ties of Organizational Belonging Understanding the Roles of Perceived Insider Status, Psychological Ownership, and Organizational Identification, Journal of Leadership \& Organizational Studies, 1-13.

Lee, J. and Suh, A. (2015). How Do Virtual Community Members Develop Psychological Ownership and What are The Effects of Psychological Ownership in Virtual Communities?, Computers in Human Behavior, 45, 382-391.

Levinson, H. (1965). Reciprocation: The Relationship between Man and Organization. Administrative Science Quarterly, 9, 370-390.

Liu, J., Wang, H., Hui, C. and Lee, C. (2012). Psychological Ownership: How Having Control Matters, Journal of Management Studies, 49(5), 869-895. 
Journal of Global Strategic Management | V. 9 | N. 2 | 2015-December | isma.info | 65-77 | DOI: 10.20460/JGSM.2015915574

Mayer, D. M., Kuenzi, M., Greenbaum, R., Bardes, M., \& Salvador, R. B. (2009). How Low Does Ethical Leadership Flow? Test of A Trickle-Down Model. Organizational Behavior and Human Decision Processes, 108(1), 1-13.

Mayer, D., Kuenzi, M., \& Greenbaum, R. (2010). Examining the Link between Ethical Leadership and Employee Misconduct: The Mediating Role of Ethical Climate. Journal of Business Ethics, 95, 7-16.

Mayhew, M. G., Ashkanasy, N. M., Bramble, T. and Gardner, J. (2007). A Study of the Antecedents and Consequences of Psychological Ownership in Organizational Settings, The Journal of Social Psychology, 147(5), 477-500.

Mcintyre, N., A. Srivastava and J.A. Fuller (2009), The Relationship of Locus of Control and Motives with Psychological Ownership in Organizations, Journal of Managerial Issues, 21(3), 383-401.

Moorman, R. H., Blakely, G. L., \& Niehoff, B. P. (1998). Does Perceived Organizational Support Mediate the Relationship between Procedural Justice and Organizational Citizenship Behavior?. Academy of Management journal, 41(3), 351-357.

O’Driscoll, M. P., Pierce, J. L. and Coghlan, A. M. (2006). The Psychology of Ownership Work Environment Structure, Organizational Commitment, and Citizenship Behaviors”, Group \& Organization Management, 31(3), 388-416.

Olckers, C. and Van Zyl, L. (2015). The Relationship between Employment Equity Perceptions and Psychological Ownership in a South African Mining House: The Role of Ethnicity, Social Indicators Research, 1-15.

Ötken, A. B. (2015). Algılanan Örgütsel Destek ve Psikolojik Sahiplenme Arasındaki İlişki ve Bu İlişkide Örgütsel Adaletin Rolü, Hacettepe Üniversitesi İktisadi ve İdari Bilimler Fakültesi Dergisi, 33(2).

Özler, H., Yılmaz, A. and Özler, D. (2008). Psychological Ownership: An Empirical Study on Its Antecedents and Impacts upon Organizational Behaviors, Problems and Perspectives in Management, 6(3), 38-47.

Özsahin, M., Zehir, C., \& Acar, A. Z. (2011). Linking leadership style to firm performance: the mediating effect of the learning orientation. Procedia-Social and Behavioral Sciences, 24, 1546-1559.

Piccolo, R. F., \& Colquitt, J. A. (2006). Transformational Leadership and Job Behaviors: The Mediating Role of Core Job Characteristics. Academy of Management journal, 49(2), 327-340.

Pierce, J. L., Kostova, T., \& Dirks, K. T. (2001). Toward a Theory of Psychological Ownership In Organizations. Academy of Management Review, 26(2), 298-310.

Pierce, J. L., Kostova, T., \& Dirks, K. T. (2003). The State of Psychological Ownership: Integrating And Extending A Century of Research. Review of General Psychology, 7(1), 84.

Qiu, M., Hu, B., Xu, Z. and Li, Y. (2015). Employees' Psychological Ownership and Self-Efficacy as Mediators between Performance Appraisal Purpose and Proactive Behavior, Social Behavior and Personality: An International Journal, 43(7), 1101-1109.

Rhoades, L., \& Eisenberger, R. (2002). Perceived Organizational Support: A Review of The Literature. Journal of Applied Psychology, 87(4), 698.

Rivkin, W., Diestel, S., \& Schmidt, K. H. (2014). The Positive Relationship between Servant Leadership and Employees’ Psychological Health: A Multi-Method Approach. Zeitschrift für Personalforschung, 28(1-2), 52-72.

Robbins, T. L., Summers, T. P., Miller, J. L. And Hendrix,W. H. (2000). Using the Group-Value Model to Explain The Role of Non-Instrumental Justice in Distinguishing The Effects of Distributive and Procedural Justice, Journal of Occupational and Organizational Psychology, 73, 511-518.

Roch, S. G. And Shanock, L. R. (2006). Organizational Justice in An Exchange Framework: Clarifying Organizational Justice Distinctions, Journal of Management, 32, 299-322. 
Rudmin, F. W., \& Berry, J. W. (1987). Semantics of Ownership: A Free-Recall Study of Property. The Psychological Record, 37, 257-268.

Shanock, L. R., \& Eisenberger, R. (2006). When Supervisors Feel Supported: Relationships with

Subordinates' Perceived Supervisor Support, Perceived Organizational Support, and Performance. Journal of Applied psychology, 91(3), 689.

Shore, L. M., \& Shore, T. H. (1995). Perceived Organizational Support and Organizational Justice. In R. S. Cropanzano \& K. M. Kacmar (Eds.), Organizational Politics, Justice, And Support: Managing The Social Climate Of The Workplace (pp. 149-164). Westport, CT: Quorum.

Shore, L. M., \& Wayne, S. J. (1993). Commitment and Employee Behavior: Comparison of Affective Commitment and Continuance Commitment with Perceived Organizational Support. Journal of Applied Psychology, 78(5), 774.

Sieger, P., Bernhard, F. and Frey, U. (2011). Affective Commitment and Job Satisfaction among Non-Family Employees: Investigating the Roles of Justice Perceptions and Psychological Ownership, Journal of Family Business Strategy, 2(2), 78-89.

Smith, C. (2015). Servant Leadership: The Leadership Theory of Robert K. Greenleaf, Retrieved November 24, 2015 from http://www.carolsmith.us/downloads/640greenleaf.pdf

Tyler, T. R. And Blader, S. L. (2003). “The Group Engagement Model: Procedural Justice, Social Identity, and Cooperative Behavior”, Personality and Social Psychology Review, 7, 349-361.

Uddin, M. A., Rahman, M. S., \& Howlader, M. H. R. (2014). Exploring The Relationships among Transformational Leadership, Deviant Workplace Behavior, And Job Performance: An Empirical Study. ABAC Journal, 34(1), 1-12.

Ürü Sanı, O., Çalişkan, S. C., Atan, Ö., \& Yozgat, U. (2013). Öğretim Üyelerinin Hizmetkâr Liderlik Davranışları ve Ardıllari Üzerine Bir Araştırma. Ege Academic Review, 13(1), 63-82.

Vandewalle, D., Van Dyne, L. and Kostova, T. (1995). Psychological Ownership: An Empirical Examination of Its Consequences, Group \& Organization Management, 20(2), 210-226.

Van Dyne, L. and Pierce, J. L. (2004). Psychological Ownership and Feelings of Possession: Three Field Studies Predicting Employee Attitudes and Organizational Citizenship Behavior, Journal of Organizational Behavior, 25(4), 439-459.

Van Gils, S., Van Quaquebeke, N., van Knippenberg, D., van Dijke, M., \& De Cremer, D. (2015). Ethical Leadership and Follower Organizational Deviance: The Moderating Role Of Follower Moral Attentiveness. The Leadership Quarterly, 26(2), 190-203.

Vondey, M. (2010). The Relationships among Servant Leadership, Organizational Citizenship Behavior, Person-Organization Fit, and Organizational Identification. International Journal of Leadership Studies, 6(1), $3-27$.

Wagner, S. H., Parker, C. P. and Christiansen, N. D. (2003). Employees That Think and Act Like Owners: Effects of Ownership Beliefs and Behaviors on Organizational Effectiveness, Personnel Psychology, 56(4), 847-871.

Wayne, S. J., Shore, L. M., \& Liden, R. C. (1997). Perceived Organizational Support and Leader-Member Exchange: A Social Exchange Perspective. Academy of Management journal, 40(1), 82-111.

Wu, C. C., \& Liu, N. T. (2014). Perceived Organizational Support, Organizational Commitment and ServiceOriented Organizational Citizenship Behaviors. International Journal of Business and Information, 9(1), 6188.

Yukl, G. A. (2002). Leadership in organizations (5th ed.). Englewood Cliffs, NJ: Prentice Hall.

Yildız, B. (2015). The Antecedents of Constructive and Destructive Deviant Workplace Behavior, Unpublished Doctoral Dissertation, Gebze Technical University, Gebze, Turkey. 
Journal of Global Strategic Management | V. 9 | N. 2 | 2015-December | isma.info | 65-77 | DOI: 10.20460/JGSM.2015915574

Yıldız, B., Alpkan, L., Ateş, H. and Sezen, B. (2015a). Determinants of Constructive Deviance: The Mediator Role of Psychological Ownership, International Business Research. 8(4), 107-121.

Yildız, B., Alpkan, L. and Sezen, B. (2015b). The Antecedents of Deviant Workplace Behaviors: A Perception, Attitude and Personality-Based Approach to Constructive and Destructive Deviant Workplace Behaviors, Germany: Scholar’s Press, ISBN:978-3-639-86089-4.

Yıldız, B., Erat, S., Alpkan, L., Yıldız, H. \& Sezen, B. (2015c). Drivers of Innovative Constructive Deviance: A Moderated Mediation Analysis, Procedia-Social and Behavioral Sciences, (195) 1407-1416.

Zehir, C., \& Erdogan, E. (2011). The Association between Organizational Silence and Ethical Leadership Through Employee Performance. Procedia-Social and Behavioral Sciences, 24, 1389-1404.

Zehir, C., Elçi, M., \& Savi, F. Z. (2003). Ethical Climate’s Relationship to Job Satisfaction, Organizational Commitment and Turnover Intention” Ethics 2003 Business and Professional Ethics Conference, Hacettepe University, Ankara, Turkey.

Zehir, C., Ertosun, Ö. G., Zehir, S., \& Müceldili, B. (2011). The Effects of Leadership Styles And Organizational Culture over Firm Performance: Multi-National Companies In İstanbul. Procedia-Social and Behavioral Sciences, 24, 1460-1474.

Zehir, C., Müceldili, B., \& Zehir, S. (2012b). The Moderating Effect of Ethical Climate on the Relationship between Job Satisfaction and Organizational Commitment: Evidence from Large Companies in Turkey. Procedia-Social and Behavioral Sciences, 58, 734-743.

Zehir, C., Sehitoglu, Y., \& Erdogan, E. (2012a). The Effect of Leadership and Supervisory Commitment to Organizational Performance. Procedia-Social and Behavioral Sciences, 58, 207-216. 